\title{
Correction to: An elliptic regularity theorem for fractional partial differential operators
}

\author{
Arran Fernandez ${ }^{1}$ (D)
}

Published online: 6 June 2018

(C) The Author(s) 2018

\section{Correction to: Comp. Appl. Math. https://doi.org/10.1007/s40314-018-0618-2}

The article "An elliptic regularity theorem for fractional partial differential operators", written by Arran Fernandez, was originally published electronically on the publisher's internet portal (currently SpringerLink) on May 02, 2018 without open access.

With the author's decision to opt for Open Choice the copyright of the article changed on May 12, 2018 to (C) The Author(s) [2018] and the article is forthwith distributed under the terms of the Creative Commons Attribution 4.0 International License (http://creativecommons.org/ licenses/by/4.0/), which permits use, duplication, adaptation, distribution and reproduction in any medium or format, as long as you give appropriate credit to the original author(s) and the source, provide a link to the Creative Commons license and indicate if changes were made.

The original article has been corrected.

Open Access This article is distributed under the terms of the Creative Commons Attribution 4.0 International License (http://creativecommons.org/licenses/by/4.0/), which permits use, duplication, adaptation, distribution and reproduction in any medium or format, as long as you give appropriate credit to the original author(s) and the source, provide a link to the Creative Commons license and indicate if changes were made.

The original article can be found online at https://doi.org/10.1007/s40314-018-0618-2.

Arran Fernandez af454@cam.ac.uk

1 Department of Applied Mathematics and Theoretical Physics, University of Cambridge, Cambridge CB3 0WA, UK 